\title{
Pengaruh Kompetensi Pelatihan Dan Supervisi Terhadap Kinerja Karyawan Pada Industry Perhotelan Di Kota Palopo
}

\author{
Muh. Arif Andi Manrang \\ Universitas Muhammadiyah Palopo \\ m.arifandimanrang@gmail.com \\ Saharuddin \\ Universitas Muhammadiyah Palopo \\ jafarsaharuddin157@email.com

\section{Rahmat Solling Hamid} \\ Universitas Muhammadiyah Palopo \\ rahmadshamid@umpalopo.ac.id
}

\begin{abstract}
Abstrak This study aims to determine the effect of competence, training and supervision on employee performance. The object of research is all hospitality agencies in the city of Palopo. The population is 17 hotels. Determination of the sample purposive sampling technique is the technique of determining the sample with certain considerations. Collecting data using a questionnaire with data analysis using multiple linear regression. using the help of SPSS version 20. The results show that: First, competence has a significant influence on employee performance. Second, training has a significant effect on employee performance. Third, supervision has a significant effect on employee performance.
\end{abstract}

Kata Kunci Kompetensi, pelatihan, supervisi dan Kinerja karyawan

\section{PENDAHULUAN}

Era kompetisi global setiap perusahaan menghadapi tingkat persaingan yang semakin tajam. Untuk menghadapi persaingan tersebut, perusahaan seharusnya memiliki keunggulan kompetitif tertentu dibandingkan dengan pesaingnya. Perusahaan yang memili keunggulan kompetitif umumnya memiliki sumber-sumber yang dapat diandalkan dalam rangka memenangkan persaingan. Salah satu sumber daya tersebut adalah sumber daya manusia. Sumber daya manusia perlu lebih dioptimalkan agar dapat meningkatkan daya saingnya, (Macmud dan Sidharta, 2016).

Dalam menjalankan sebuah usaha khususnya bidang perhotelan pihak manajemen harus mempunyai strategi yang bagus dan kompeten untuk meningkatan kualitas sumber daya manusia. Karena dengan pngarahan dan dukungan dari manajemen tertinggi, kerjasama antara pemimpindan karyawan menjadi lebih solid. Sumber daya manusia yang cakap, mampu dan terampil belum menjamin produktivitas kerja yang baik, apabila moral kerja dan disiplin dalam bekerja masih rendah. Untuk itulah sumber daya manusia perlu dikmbangkan secara terus menerus agar diperoleh sumber daya manusia yang bermutu dan pruduktif. Factor yang dianggap paling potensial dalam penyediaan 
keunggulan kompetitif bagi perusahaan adalah sumber daya manusia, serta dengan terkaitnya bagaimana mengelola sumber daya ini, (Suwatno, 2011).

Sumber daya manusia merupakan tokoh utama di dalam setiap kegiatan perusahaan khususnya bidang perhotelan. Tanpa sumber daya yang mencukupi, sumber dana yang melimpah takkan ada gunanya. Setiap perusahaan mengiginkan peningkatan yang signifikan untuk meperoleh hasil yang diinginkan, hotel harus memperoleh, mengembagkan, dan mempertahankan kualitas sumber daya manusia yang berkualitas. Tidak hanya cukup sampai disitu, pihak hotel harus terus meningkatkan kualitas sumber daya manusia. Kualitas yang dimaksud yakni bukan menyangkut jumlah sumber daya manusia, sedangkan yang dimakasud kualitas yakni mutu sumber daya manusia yang menyangkut kemampuan, baik kemampuan fisik maupun non fisik, yang berarti juga kemampuan bekerja, berfikir, dan yang lain.

Upaya dalam mengembangkan dan menjaga eksistensi sektor perhotelan dalam perkotaan, pemerintah dan pelaku usaha perlu meningkatkan variasi pelayanan. Salah satu faktor dalam meningkatkan pelayanan yang baik yaitu dengan mempersiapkan kualitas sumber daya manusia. Selain itu perkembangan perhotelan pada kota bisnis juga sangat bergantung pada simpul transportasi nasional dan internasional sebagai pintu utama bisnis, perdagangan dan jasa di kota tersebut. Kompetensi dan pelatihan sangat menunjang keberhasilan suatu usaha pada bidang perhotelan tetapi kita juga tidak boleh melupakan pengawasan kerja atau supervisi yang merupakan suatu hal yang wajib dilakukan dalam perusahaan untuk meningkatkan kinerja sumber daya manusianya. Salah satu langkah meningkatkan kualitas sumber daya manusia pada hotel adalah pelatihan, (Suwarto, 2014).

\section{LANDASAN TEORI}

\section{Kompetensi}

Wibowo (2007) menyatakan kompetensi adalah suatu kemampuan untuk melaksanakan atau melakukan suatu pekerjaan yang dilandasi atas keterampilan dan pengetahuan serta didukung oleh sikap kerja yang dituntut oleh pekerjaan tersebut.

Kompetensi didefinisikan sebagai kecakapan dan kemampuan yang diartikan secara lugas karakteristik dasar perilaku individu yang berisi gambaran motif, konsep diri, nilai-nilai, pengetahuan atau keahlian yang ditunjukkan individu yang berkinerja unggul (Abel, 2008). Secara lebih spesifik, kompetensi dipahami sebagai kombinasi: 1) pengetahuan, yakni kemampuan prosedural bersifat teknis seperti kemampuan menganalisa keuangan, ahli komputer, jurnalistik dan sebagainya; 2) keahlian manajerial, yakni kemampuan mengembangkan orang lain dan membangun kerjasama tim; 3) karakteristik pribadi, yaitu kemampuan adaptasi, percaya diri, tahan stress, integritas, dan sebagainya (Lindner, 2001).

Kompetensi bukan merupakan kemampuan yang tidak dapat dipengaruhi. Michael dalam Wibowo (2010) mengungkapkan bahwa terdapat beberapa faktor yang dapat mempengaruhi kecakapan kompetensi seseorang, yaitu:

(1) Keterampilan memainkan peran dikebanyakan kompetensi. Berbicara di depan umum merupakan keterampilan yang dapat dipelajari, dipraktikkan, dan diperbaiki. Keterampilan menusia juga bisa diperbaiki dengan interuksi, praktik dan umpan balik. dengan memperbaiki keterampilan berbicara di depan umum dan menulis, individu akan 
meningkat kecakapannya dalam kompetensi tentang perhatian terhadap komunikasi. Pengembangan keterampilan yang secara spesifik berkaitan dengan kompetensi dapat berdampak baik pada budaya organisasi dan kompetensi individual. (2) Pengalaman, Keahlian dari banyak kompetensi memerlukan pengalaman mengorganisasi orang, komunikasi di hadapan kelompok, menyelesaikan masalah, dan sebagainya. Orang yang tidak pernah berhubungan dengan organisasi besar dan komplek tidak mungkin mengembangkan kecerdasan organisasional untuk memahami dinamika kekuasaan dan pengaruh dalam lingkungan seperti tersebut. (3) karakterstik kepribadian dalam kepribadian termasuk banyak faktor yang diantaranya sulit untuk berubah. Akan tetapi kepribadian seseorang dapat berubah sepanjang waktu. Orang merespons dan beriteraksi dengan kekuatan dan lingkungan sekitar. Kepribadian dapat mempengaruhi keahlian menejer dan pekerja dalam sejumlah kompetensi, termasuk dalam penyelesaian konflik, menunjukkan kepedulian interpersonal, kemampuan bkerja dalam tim, memberikan pengaruh dan pembangunan hubungan. (4) kemampuan intelektual kompetensi tergantung pada pemikiran kognitif seperti pemikiran konseptual dan pemikiran analitis. Tidak mungkin memperbaiki melalui setiap intervensi yang diwujudkan suatu organisasi.

\section{Pelatihan}

Menurut Dessler (2008) pelatihan merupakan proses terintegrasi yang digunakan oleh pengusaha untuk memastikan agar para karyawan bekerja untuk mencapai tujuan organisasi. Artinya bahwa perusahaan melakukan pendekatan terintegrasi dan berorientasi pada tujuan dengan cara menugaskan, melatih, menilai dan memberikan penghargaan pada kinerj karyawan. Diana Aqmala (2007) mengemukakan bahwa ada beberapa faktor yang mempengaruhi pelatihan yaitu: 1) Ketepatan Metode Pelatihan. Dalam kamus dikatakan bahwa metode berarti cara. Ketepatan metode pelatihan berarti ketepatan cara penyampaian yang digunakan selama pelatihan itu berlangsung. 2) Kualitas Isi Pelatihan Kualitas dari isi pelatihan merupakan hal yang perlu diperhatikan sebab semakin berkualitas isi atau materinya akan semakin mengoptimalkan manfaat dari pelatihan yang berarti semakin efektif pula pelatihan 3) Kualitas Trainer. adanya trainer yang berkualitas berdampak pada keberhasilan dari pelaksanaan pelatihan. Keberhasilan pelaksanaan pelatihan berkaitan erat dengan bertambahnya pengetahuan dan kemampuan peserta yang merupakan indikator dari efektivitas pelatihan.

\section{Supervisi}

Sindu Mulianto, et al, (2006) mendefinisikan sebagai: supervision is the achieving of desired result by means of the intelligent utilization of human talent and facilitating resources in a manner that provides the greatest challenge and interest to the human talents (supervisi adalah usaha mencapai hasil yang diinginkan dengan cara mendayagunakan bakat atau kemampuan alami manusia dan sumber-sumber yang memfasilitasi, yang ditekankan pada pemberian tantangan dan perhatian yang sebesarbesarnya terhadap bekat atau kemampuan alami manusia).

Indikator yang dapat mengukur pengawasan/supervisi : (1) ukuran atau Standar pekerjaan, sebelum pengawasan dilaksanakan terlebih dahulu menetapkan standar atau ukuran. Perencanaan pengawasan juga bisa disebut sebagai penetapan standar, (2) Penilaian pekerjaan, Penilaian atau pengukuran pekerjaan adalah mengukur atau menilai kinerja yang dicapai oleh pegawai. Dalam melakukan pengukuran pekerjaan harus tepat sehingga dapat dihilangkan adanya perbedaan penting antara yang sedang terjadi dengan 
apa yang semula diinginkan sesuai rencana. (3) Perbandingan antara hasil pekerjaan dengan ukuran atau standar pekerjaan, Perbandingan hasil kerja dengan ukuran merupakan ukuran dalam satu tindakan penting dalam menetukan baik atau buruk pengendalian yang terjadi pada situasi tersebut. Perbandingan antara kinerja yang dicapai serta perencanaan kinerja yang diinginkan akan menentukan tindakan yang akan diambil.(4) Perbaikan atas penyimpangan, Tindakan perbaikan atau koreksi dilaksanakan apabila dalam pelaksanaan pekerjaan ditemukan penyimpangan atau kesalahan. Dalam manajemen, bila ada suatu kesalahan dalam pekerjaan, maka kesalahan harus segera diperbaiki. Perbaikan yang dilakukan juga harus mengacu kepada peraturan organisasi dan mengarah kepada tujuan organisasi. Melalui tindakan perbaikan terhadap satu penyimpangan, diharapkan hasil kerja akan sesuai dengan rencana.

\section{4. kinerja karyawan}

Kinerja dapat mempengaruhi kegiatan operasional organisasi, semakin tinggi kinerja yang ditunjukkan karyawan maka semakin tinggi pula kinerja organisasi. Wibowo (2009) Kinerja berasal dari makna kinerja. Orang lain juga memberikan pemahaman tentang kinerja sebagai kinerja, hasil kerja, atau prestasi. Memang, kinerja memiliki makna yang lebih luas, tidak hanya mencakup hasil kerja, tetapi juga bagaimana cara kerja diproses. Pencapaian kinerja yang dapat diraih oleh seorang karyawan dapat dipengaruhi dari berbagai faktor Menurut (Mutiara Amran, 2018) Terdapat empat faktor yang dapat mempengaruhi kinerja yaitu: 1) Pegawai, berkenaan dengan kemampuan dan kemauan dalam melaksanaan pekerjaan. 2) Pekerjaan, menyangkut desain pekerjaan, uraian pekerjaan dan sumber daya untuk melaksanakan pekerjaan. 3) Mekanisme kerja, mencakup system, prosedur pendelegasian dan serta pengendalian serta struktur organisasi. 4) Lingkungan kerja, meliputi faktor-faktor lokasi dan kondidi kerja, iklim organisasi dan komunikasi, Penerapan fator-faktor tersebut, dapat membantu meningkatkan kinerja karyawan. Dalam kata lain, apabila faktor tersebut terpenuhi maka kinerja karyawan akan meningkat.

\section{METODE PENELITIAN}

Penelitian ini menggunakan pendekatan penelitian kuantitatif dalam usaha menguji hipotesis yang telah disusun. Penelitian kuantitatif adalah suatu penelitian yang pada dasarnya menggunakan pendekatan deduktif-induktif. Pendekatan ini berangkat dari suatu kerangka teori, gagasan para ahli, maupun pemahaman peneliti berdasarkan pengalamannya, kemudian dikembangkan menjadi permasalahan-permasalahan yang diajukan untuk memperoleh pembenaran (verifikasi) atau penolakan dalam bentuk dokumen data empiris lapangan (wibowo, 2009). Penelitian kuantitatif juga banyak menggunakan angka, mulai dari pengumpulan data, penafsiran angka tersebut, serta penampilan dari hasilnya. Penelitian ini dilakukan pada industri perhotelan di kota Palopo. Waktu penelitian dimulai pada saat penulis mengajukan proposal untuk penelitian ini yaitu dimulai dari bulan Februari sampai Mei 2021. Sugiyono (2014) menyatakan bahwa "Populasi adalah wilayah generalisasi yang terdiri atas obyek/subyek yang mempunyai kualitas dan karakteristik tertentu yang ditetapkan oleh peneliti untuk dipelajari dan kemudian ditarik kesimpulannya.". Populasi yang digunakan dalam penelitian ini adalah seluruh industri perhotelan yang ada dikota palopo dengan teknik pengambilan sampel menggunakan metode purposive sampling yaitu teknik penentuan sampel dengan pertimbangan tertentu. Kriteria yang digunakan untuk pemilihan sampel 
dalam penelitian ini adalah sebagai berikut. (1) Manager atau orang yang bertanggung jawab pada hotel, (2) Karyawan yang sudah bekerja di atas 2 tahun.

Defenisi operasional adalah unsur penelitian yang memberitahukan bagaimana caranya mengukur suatu variabel. Dengan kata lain defenisi operasional adalah semacam petunjuk pelaksanaan bagaimana caranya mengukur suatu variabel. Dalam penelitian ini ada 3 (tiga) variabel independen yaitu kompetensi, pelatihan dan supervisi. Sedangkan variabel dependen yaitu Kinerja Karyawan.

\section{HASIL PENELITIAN}

Metode pengumpulan data dalam penelitian ini adalah dengan memberikan kuesioner kepada setiap responden pada objek penelitian pada industri perhotelan dikota Palopo. Kuesioner dibagikan kepada 60 karyawan yang bekerja di berbagai hotel yang ada di Palopo. Dari total 60 eksamplar kuesioner, terdapat 48 kuesioner yang kembali dan memenuhi syarat untuk diolah,

Tabel 4.7 Rekapitulasi Pengujian Validitas

\begin{tabular}{|c|c|c|c|}
\hline Variabel & Indikator & Korelasi & Keterangan \\
\hline \multirow{4}{*}{ Kompetensi (X1) } & $\mathrm{X} 1.1$ & 0,331 & Valid \\
\hline & $\mathrm{X} 1.2$ & 0,702 & Valid \\
\hline & $\mathrm{X} 1.3$ & 0,741 & Valid \\
\hline & $\mathrm{X} 1.4$ & 0,641 & Valid \\
\hline \multirow{4}{*}{ Pelatihan (X2) } & $\mathrm{X} 2.1$ & 0,658 & Valid \\
\hline & $\mathrm{X} 2.2$ & 0,574 & Valid \\
\hline & $\mathrm{X} 2.3$ & 0,405 & Valid \\
\hline & $\mathrm{X} 2.4$ & 0,755 & Valid \\
\hline \multirow{4}{*}{ Supervisi (X3) } & $\mathrm{X} 3.1$ & 0,487 & Valid \\
\hline & $\mathrm{X} 3.2$ & 0,844 & Valid \\
\hline & X3.3 & 0,900 & Valid \\
\hline & $\mathrm{X} 3.4$ & 0,866 & Valid \\
\hline \multirow{4}{*}{ Kinerja Karyawan (Y) } & Y.1 & 0,719 & Valid \\
\hline & Y.2 & 0,666 & Valid \\
\hline & Y.3 & 0,721 & Valid \\
\hline & Y.4 & 0,552 & Valid \\
\hline
\end{tabular}

Table 4.7 menunjukkan nilai korelasi semua item pernyataan pada kuesioner keseluruhan indikator dan item dengan nilai diatas 0.284 (> 0.284), sehingga dapat disimpulkan bahwa semua item pertanyaan pada instrument tersebut dinyatakan valid.

\begin{tabular}{|c|c|c|c|}
\hline Variabel & $\begin{array}{c}\text { Standar Koefisien } \\
\text { Alpha }\end{array}$ & Cronbach's Alpha & Keterangan \\
\hline Kompetensi $\left(\mathrm{X}^{1}\right)$ & 0.70 & 0,727 & Reliabel \\
\hline Pelatihan $\left(X^{2}\right)$ & 0.70 & 0,723 & Reliabel \\
\hline Supervisi $\left(\mathrm{X}^{3}\right)$ & 0.70 & 0,811 & Reliabel \\
\hline Kinerja Karyawan (Y) & 0.70 & 0,761 & Reliabel \\
\hline
\end{tabular}

Sumber: Data Primer Diolah, 2021 
Table 4.8 menunjukkan bahwa nilai cronbach's alpha seluruh variabel lebih besar dari nilai standar koefisien alpha 0,7 . Hal ini berarti instrument yang digunakan penelitian ini adalah reliabel (andal).

Tabel 4.9 Hasil Uji Normalitas

One-Sample Kolmogorov-Smirnov Test

\begin{tabular}{|c|c|c|}
\hline & & $\begin{array}{c}\text { Unstandardized } \\
\text { Residual }\end{array}$ \\
\hline \multicolumn{2}{|l|}{$\mathrm{N}$} & 48 \\
\hline \multirow{3}{*}{ Normal Parameters ${ }^{\mathrm{a}, \mathrm{b}}$} & Mean & 0E-7 \\
\hline & Std. Deviation & .35534545 \\
\hline & Absolute & .077 \\
\hline \multirow[t]{2}{*}{ Most Extreme Differences } & Positive & .074 \\
\hline & Negative & -.077 \\
\hline Kolmogorov-Smirnov Z & & .535 \\
\hline Asymp. Sig. (2-tailed) & & .937 \\
\hline
\end{tabular}

a. Test distribution is Normal.

b. Calculated from data.

Sumber: Data Primer Diolah, 2021

Berdasarkan tabel 4.9 uji normalitas menunjukkan nilai Asymp. Sig (2-tailed) sebesar 0,937. Hasil tersebut menunjukkan bahwa data berdistribusi normal karena nilai Sig (2tailed) $>0,05$. Dengan demikian, H0 ditolak dan Ha diterima

Tabel 4.10 Hasil Uji Multikolonearitas

\begin{tabular}{|l|c|c|c|}
\hline \multicolumn{1}{|c|}{ Variabel } & Tolerance & VIF & Keterangan \\
& & & \\
\hline Kompetensi $\left(\mathrm{X}^{1}\right)$ & 0.691 & 1.447 & Non Multikolinearitas \\
\hline Pelatihan $\left(\mathrm{X}^{2}\right)$ & 0.607 & 1.647 & Non Multikolinearitas \\
\hline Supervisi $\left(\mathrm{X}^{3}\right)$ & 0.759 & 1.318 & Non Multikolinearitas \\
\hline
\end{tabular}

Sumber: Data Primer Diolah, 2021

Berdasarkan tabel 4.10, semua variabel menunjukkan nilai tolerance $>0,10$, dan nilai VIF $<10$, sehingga dapat disimpulkan bahwa model regresi pada penelitian ini bebas dari masalah multikolinearitas. Oleh karena itu model regresi layak untuk digunakan dalam penelitian. 


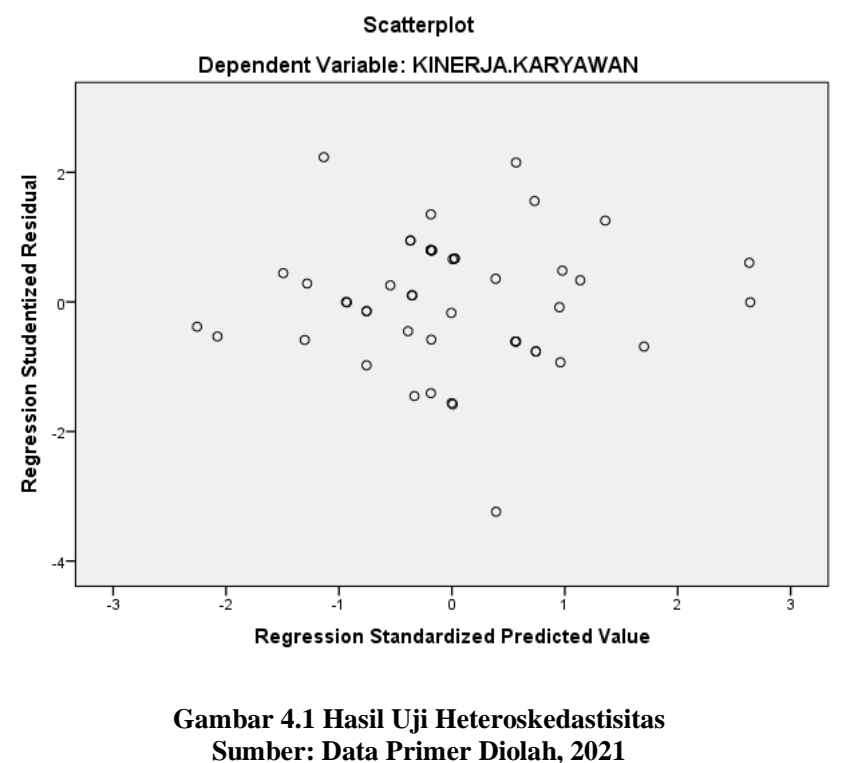

Hasil grafik scatterplot pada gambar 4.1 terlihat bahwa titik-titiknya menyebar secara acak baik diatas maupun dibawah nol pada sumbuh Y dan tidak membentuk pola tertentu. Sehingga dapat ditarik kesimpulan bahwa tidak terjadi heterokedastisitas pada model regresi.

Tabel 4.11 Uji Statistik $t$

\begin{tabular}{|c|c|c|c|c|c|c|}
\hline \multicolumn{7}{|c|}{ Coefficients $^{\mathrm{a}}$} \\
\hline \multirow{2}{*}{\multicolumn{2}{|c|}{ Model }} & \multicolumn{2}{|c|}{$\begin{array}{l}\text { Unstandardized } \\
\text { Coefficients }\end{array}$} & \multirow{2}{*}{$\begin{array}{c}\begin{array}{c}\text { Standardized } \\
\text { Coefficients }\end{array} \\
\text { Beta }\end{array}$} & \multirow[t]{2}{*}{$\mathrm{t}$} & \multirow[t]{2}{*}{ Sig. } \\
\hline & & B & Std. Error & & & \\
\hline \multirow{4}{*}{1} & (Constant) & 8.592 & 0.279 & & 30.845 & 0,000 \\
\hline & Kompetensi & 0.580 & 0.132 & 0.456 & 4.385 & 0,000 \\
\hline & Pelatihan & 0.351 & 0.069 & 0.325 & 5.092 & 0,000 \\
\hline & Supervisi & 0.168 & 0.063 & 0.241 & 2.682 & 0,010 \\
\hline
\end{tabular}

Sumber: Data Primer Diolah, 2021

1. Hipotesis yang pertama diketahui untuk kompetensi $\left(\mathrm{X}^{\mathrm{I}}\right) \mathrm{t}_{\text {hitung }}=4,384>\mathrm{t}_{\text {tabel }}=1,679$ dengan signifikansi $0,000<0,05$ artinya terdapat pengaruh dan signifikan dalam meningkatkan kinerja karyawan.

2. Hipotesis yang pertama diketahui untuk pelatihan $\left(X^{2}\right) t_{\text {hitung }}=5.092>t_{\text {tabel }}=1,679$ dengan signifikansi $0,000<0,05$ artinya terdapat pengaruh dan signifikan dalam meningkatkan kinerja karyawan.

3. Hipotesis yang pertama diketahui untuk supervisi $\left(X^{3}\right) t_{\text {hitung }}=2.682>t_{\text {tabel }}=1,679$ dengan signifikansi $0,010<0,05$ artinya terdapat pengaruh dan signifikan dalam meningkatkan kinerja karyawan. 
Tabel 4.12 Uji Koefisien Determinasi $\left(\mathrm{R}^{2}\right)$

\begin{tabular}{|c|c|c|c|c|}
\hline \multicolumn{5}{|c|}{ Model Summary } \\
\hline Model & $\mathrm{R}$ & R Square & $\begin{array}{l}\text { Adjusted R } \\
\text { Square }\end{array}$ & $\begin{array}{l}\text { Std. Error of the } \\
\text { Estimate }\end{array}$ \\
\hline 1 & $.975^{\mathrm{a}}$ & 0.951 & 0.947 & 0.1037 \\
\hline \multicolumn{5}{|c|}{ a. Predictors: (Constant), Supervisi, Pelatihan, Kompetensi } \\
\hline \multicolumn{5}{|c|}{ b. Dependent Variable: Kinerja.Karyawan } \\
\hline
\end{tabular}

Hasil uji Adjusted $R^{2}$ menunjukkan nilai koefisien determinasi $R$ square sebesar 0,947 atau 94,7\%. Hal ini mengindikasikan bahwa kinerja karyawan (Y) dipengaruhi sebesar 94,7\% oleh kompetensi (X1), pelatihan (X2), dan supervisi (X3). Adapun sisanya sebesar $5,3 \%$ dipengaruhi variabel lain diluar penelitian ini.

Tabel 4.13 Uji Signifikansi Simultan (Uji F)

\begin{tabular}{|c|c|c|c|c|c|c|}
\hline \multicolumn{7}{|c|}{ ANOVA $^{\mathrm{a}}$} \\
\hline \multicolumn{2}{|l|}{ Model } & $\begin{array}{c}\text { Sum of } \\
\text { Squares }\end{array}$ & df & Mean Square & $\mathrm{F}$ & Sig. \\
\hline \multirow{3}{*}{1} & Regression & 9.139 & 3 & 3.046 & 283.277 & $.000^{\mathrm{b}}$ \\
\hline & Residual & 0.473 & 44 & 0.011 & & \\
\hline & Total & 9.612 & 47 & & & \\
\hline \multicolumn{7}{|c|}{ a. Dependent Variable: Kinerja.Karyawan } \\
\hline \multicolumn{7}{|c|}{ b. Predictors: (Constant), Supervisi, Pelatihan, Kompetensi } \\
\hline
\end{tabular}

Hasil uji simultan $\mathrm{F}$ diperoleh nilai $\mathrm{F}_{\text {hitung }} 283.277>\mathrm{F}_{\text {tabel }}$ 2,82 dan tingkat signifikansi sebesar 0,000. Dilihat dari nilai signifikansinya, maka nilai signifikansi tersebut lebih kecil dari 0,05, yang berarti bahwa variabel kompetensi, pelatihan dan supervisi secara simultan berpengaruh terhadap kinerja karyawan.

\section{KESIMPULAN}

Kompetensi memiliki pengaruh signifikan terhadap Kinerja karyawan. Hal ini menandakan bahwa peningkatan kompetensi setiap karyawan akan meningkatkan loyalitas dan memberikan dedikasi kinerja karyawan yang baik terhadap industry perhotelan di kota palopo. (2) Pelatihan memiliki pengaruh signifikan terhadap kinerja karyawan. Hal ini mengindikasikan bahwa Pelatihan yang dilakukan oleh setiap karyawan akan menimbulkan suatu kinerja yang baik dari setiap karyawan untuk dapat memotivasi karyawan dalam memberikan kinerjanya yang terbaik terhadap industry perhotelan di kota palopo. (3) Supervisi memiliki pengaruh signifikan terhadap kinerja karyawan. Hal ini menandakan bahwa adanya supervisi sebagai pengamat kerja menjadikan peningkatan kinerja terhadap pegawai puskesmas dikarenakan adanya pantauan sehingga dapat bekerja menjadi lebih teliti dan lebih baik lagi serta semakin giat dalam bekerja.

\section{DAFTAR PUSTAKA}

Abel, Marie-Helene. 2008. "Competencies and Learning Organizational Memory". Journal of Knowledge Management. Vol. 12, (6), pp: 15-30. 
Aqmala, Diana. 2007. Analisis Faktor-Faktor Yang Mempengaruhi Efektivitas Pelatihan Penjualan dan Kompetensi Untuk Meningkatkan Kinerja Tenaga Penjualan. Tesis. Magister Manajemen Universitas Diponegoro. Semarang

Dessler, Gary. 2011. Manajemen sumber daya manusia. Penerbit Indeks, Jakarta.

Lindner, James R. 2001. "Competency Assessment and Human Resource Management Performance of County Extension Chairs". Journal of Southern Agricultural Education Research. Vol. 51, (1), pp: 333-346.

Machmud, S., \& Sidharta, I. 2016. Enterpreneurial Motivation And Business Performance Of Smes In The SUCI Clothing Center, Bandung Indonesia. DLSU Business \& Economics Review, 25(2),63-78.

Murtia Arman \& Kasmita. 2018. Pengaruh Pengawasan Supervisor Di Room Division Terhadap Kinerja Karyawan Hotel Axana Padang. Jurnal PTK: Research and Learning in Vocational Education. 1(4), 2621

Sindu Mulianto, dkk, 2006. "Panduan Lengkap Supervisi Diperkaya Perspektif Syariah", Jakarta: PT Elex Media Komputindo.

Sugiyono. 2014. Metode Penelitian Kuantitatif Kualitatif dan R\&B. Bandung: Alfabeta.

Suwarto, f.x. 2014. Manajemen kinerja edisi kelima. Yogyakarta: Cahaya Atma Pustaka.

Suwatno. 2011. Manajmen SDM: Dalam Organisasi Public dan Bisnis. Bandung: Alfabeta.

Wibowo. 2016. Pengaruh Motivasi Kerja terhadap Kinerja Karyawan pada PT. Gramedia Asri Media Cabang Emerald Bintaro. Computech \& Bisnis, 119- 127. 